\title{
New Directions in the Sociology of Collective Memory and Commemoration
}

\author{
Brian Conway*
}

National University of Ireland, Maynooth

\begin{abstract}
The study of memory straddles a wide range of social science disciplines including sociology, psychology, anthropology, and geography. Within sociology, reviews of the literature have already been carried out, but these are now somewhat dated. This article takes the measure of recent prior research on the sociology of collective memory and commemoration by (1) proposing a classification of collective memory research; (2) organising the literature under the headings of theoretical developments, methodological strategies, and methodological challenges; and (3) offering suggestions for maximising the internal cohesion and external utility of the sub-field.
\end{abstract}

\section{Introduction}

Over a decade ago, sociologists Jeffrey Olick and Joyce Robbins wrote a now widely cited review in the Annual Review of Sociology (Olick and Robbins 1998) of the then (and still) emerging field of 'memory studies'. Alerting readers to the different disciplinary routes into and out of memory and to the three 'big' topics of identity, change, and persistence around which it is organised, they characterised the field as 'centerless' (Olick and Robbins 1998, 105). Since then, a number of notable developments have occurred that have helped to bring greater coherence to a somewhat inchoate field. One good example of this is the recent establishment of a specialist journal, Memory Studies. Beyond this, the past decade has also seen a flurry of articles, chapters, and books on memory projects in a wide variety of national contexts. Indeed, 'memory studies' is an umbrella term hovering up a diverse set of disciplinary vantage points, methodological approaches, and theoretical perspectives on how we collectively and corporately remember and commemorate the past.

This article seeks to give the reader a sense of this variation and complexity and, at the same time, offer some kind of synthesis of it for students of the past beginning to acquaint themselves with the specifically sociological literature on it. Given the vast body of research that now exists on memory and the constraints a relatively short review article such as this imposes, it is necessarily selective and with this in mind I hope it might invite or urge students to work 'off the page' by doing their own explorations in libraries, archives, and databases.

This review is organised into six sections. Section 1 offers a working definition of collective memory and commemoration as a basic starting point. The second section presents a brief history of memory research going back to the early sociological work of Émile Durkheim and his student Maurice Halbwachs, and then extending into the last twenty years or so of the contemporary era. Section 3 deals with theoretical developments in the field. This is followed in Section 4 by an examination of the methodological strategies sociologists use to empirically study memory as well as a brief 
discussion of methodological challenges in Section 5. Section 6 stands back from the earlier discussion and attempts to look into the future by speculating about possible fruitful pathways of enquiry for students of memory.

While memory attracts the interests of scholars from a diverse range of disciplines each with discipline-specific orientations, what sets the sociological standpoint apart is its sensitivity to the fundamentally social bases of memory - that is to say, that what, when and how we remember and commemorate is relational, that is, depends on the variable influence of others. This is not to deny that individuals 'do' memory as well, but it is to insist that they do so in the context of the prevailing conditions and circumstances of their social environment both present and inherited. A brief elaboration in the next section of what we mean by 'collective memory' and 'commemoration' helps to make this clearer.

Even a basic acquaintance with memory research quickly reveals the rich pluralism of mnemonic devices individuals and collectivities use to remember the past. These range from the better known devices such as memorials, museums, and monuments to less well-known, though increasingly widely used, means such as street murals, Internet Web sites, and consumer items like t-shirts, key rings, and CD-ROMS. These mnemonic devices are asymmetrical in terms of such things as the norms and expectations associated with interacting with them, malleability, and preservation of the past. Consider, for example, that how people behave in a museum is more subject to control by those responsible for putting it together than how people interact with Internet Web sites and that memorials are more static and less invariant in nature than Internet Web sites. In terms of the preservation of our connections to the past, museums tend to be better repositories of the past than more ephemeral, throw-away items like key-rings.

\section{Defining collective memory and commemoration}

A basic point of departure in any review article of a field is to develop some basic working understanding of its key concepts. Sociologist Barry Schwartz puts forward the following definition of collective memory: 'collective memory refers to the distribution throughout society of beliefs, feelings, moral judgements and knowledge about the past'[http://www.sociologyencyclopedia.com/info/sample1.pdf (last accessed 27 January 2010)].

This definition makes three important points. First, collective memory has to do with a societal-wide phenomenon - it is not a property of individuals but of social groups. Second, collective memory concerns how people feel about the past rather than strictly what objectively happened in the past. In this sense, collective memory has to do with what social groups select out of the happenings of their lives that they consider important and worthy of preserving. Inevitably, this normative evaluation also involves forgetting not everything about the past can be remembered, as there are limits to the capacity of our minds to process the past (Schwartz 2009; Zerubavel 1997). Memory, to use the language of economic theory, involves opportunity costs. By this account, commemorating the past is not a simple or straightforward matter. Answers to seemingly basic questions such as who should be remembered? when? and why? are rarely easy to answer, and social groups frequently fight with one another over the answers to them. A third important point that can be made in relation to this definition is that collective memory has to do with the remembered past and its connections to the lived present and the imagined future (Lewis and Weigert 1981, p. 435) - it is about the temporality of our individual and collective lives. 
As a result of a focus on these three things, sociological studies of memory have tended to suffer from two important conceptual limitations - (1) an oversocialised conception of memory that tends to sidestep the question of whether collective images of the past map onto individual reminiscences and vice versa; and (2) a tendency to homogenise collective memory and thus to underestimate the extent to which collective memory can be a container for a diversity of colliding and fragmented meanings of the past.

Collective memory and commemoration are clearly related, but they are not one and the same thing. Commemoration has to do with the practices and artefacts (Casey 2000; Olick 2008), social groups mobilise to represent the past to themselves and to others. Put another way, it relates to what people actually do in a communal way and in public contexts - commemoration basically involves public work - in response to the social distribution of opinions about the past and is the outcome of contestation, interests, and negotiation. Spaces, times, bodies, and images are cultural resources drawn upon in most commemorative activity. By contrast, collective memory is more a state of mind than a concrete set of material things and social practices - 'sites of memory' (Nora 1989) - oriented to the past, present, and future.

\section{Pathways of collective memory research}

The first sociological thoughts about memory were written by Émile Durkheim - though admittedly he did not invoke the term itself (Misztal 2003) - and he claimed religious rituals played an important role in reminding people of their pasts and connecting them to one another through this. In The Elementary Forms of Religious Life (Durkheim 1995), Durkheim was arguably more interested in time than in memory per se (Olick and Robbins 1998) - positing that our categories of time (and space) come from religion and he recognised that the social solidarity generated by it could "travel" beyond ritual occasions but that it needed to be kept fresh and live through regular commemorative practices. A second important figure in the history of the sub-field is Maurice Halbwachs, a student of Durkheim. Halbwachs's work reflected continuity with the earlier Durkheimian tradition by emphasising the socially created nature of memory via families, occupational groups, religious gatherings, and other social hosts. This social understanding was clearly reflected in the important distinction Halbwachs made between autobiographical and historical memory, which I discuss.

Both Durkheim and Halbwachs emphasised the importance of ritual and other mnemonic devices such as texts of all kinds - museums, murals, monuments, and the like that institutionalise the past in our everyday lives. Neither gave much attention, however, to the dynamic relation between embodied rituals and textual means of remembering the past (Casey 2000) or to the possibilities of cross-currents and collisions in memory as reflected in more contemporary work examining "official" versus "vernacular" renderings of the past (Gillis 1994). Despite their focus on positive pasts (Fine 2001), at least mentioning Durkheim and Halbwachs is now almost an obligatory preface comment in any serious engagement with collective memory.

Nowadays sociologists are actively engaged in memory research. Although much of this present-day research originates from and about the Anglo-American world, increasingly, less well-studied geographical areas such as Asia are receiving attention as well (Schwartz and Kim forthcoming; Tsutsui 2009). One way of gauging recent growth in interest in the field is to look at trends and patterns in the number of journal articles referring to the concept of collective memory. Since the 1960s, there has been a veritable explosion of interest in it. In the 1960-1975 period only 4 journal abstracts made 
mention of the term, but in the 2000-2010 period this had grown to 1380 (see Figure 1). While the number of periodicals also grew over this time period and helps explain the trend, the almost threefold increase in mentions of the concept from 1990-2000 to 2000-2010 is indicative of its growing popularity.

\section{Theoretical developments}

Compared to other sub-fields in sociology, the sociology of collective memory and commemoration is not well developed theoretically. Sociologists of memory tend to import concepts and theories from other sub-fields into theirs and - surprising perhaps - there is little traffic in the other direction. One rare example of traffic into other sub-disciplines from collective memory research is the use by sociologists of religion of the concept of religion as a 'chain of memory', a construct associated with the work of Hervieu-Léger (2000). In addition to the straw men "constructionist" and "continuity" perspectives (Jedlowski 2001; Olick 2008; Olick and Robbins 1998), the literature is characterised by the circulation of a plethora of concepts including memory work (Irwin-Zarecka 1994), memory entrepreneurship (Olick and Robbins 1998), memory projects (Corney 2003), autobiographical memory (Halbwachs 1992), historical memory (Halbwachs 1992), prosthetic memory (Landsberg 2004), postmemory (Hirsch 2008), cosmopolitan memory (Levy and Sznaider 2006), recovered memory (Sturken 1998), somatic memory (Gibbons 2001), cultural trauma (Alexander 2003), visual memory (Zelizer 2002), and so on. This bundle of concepts (summarised in Table 1) can be loosely distilled into three broad categories: (1) concepts relating to agency and actorhood in relation to commemoration and remembrance; (2) concepts relating to the constitutive forces for memory; and (3) concepts relating to the contexts in which memory is (re)produced. The concepts of 'memory work', 'memory entrepreneurs,' and 'memory projects' relate to agency and actorhood, the concepts of autobiographical, historical, post, and cosmopolitan memory relate to different contexts in which memory is produced while cultural trauma, somatic memory, recovered memory, and visual memory relate to different constitutive forces for memory. Space does not permit a full elaboration of each of these focal concepts, so I have chosen to hone in on six of them.

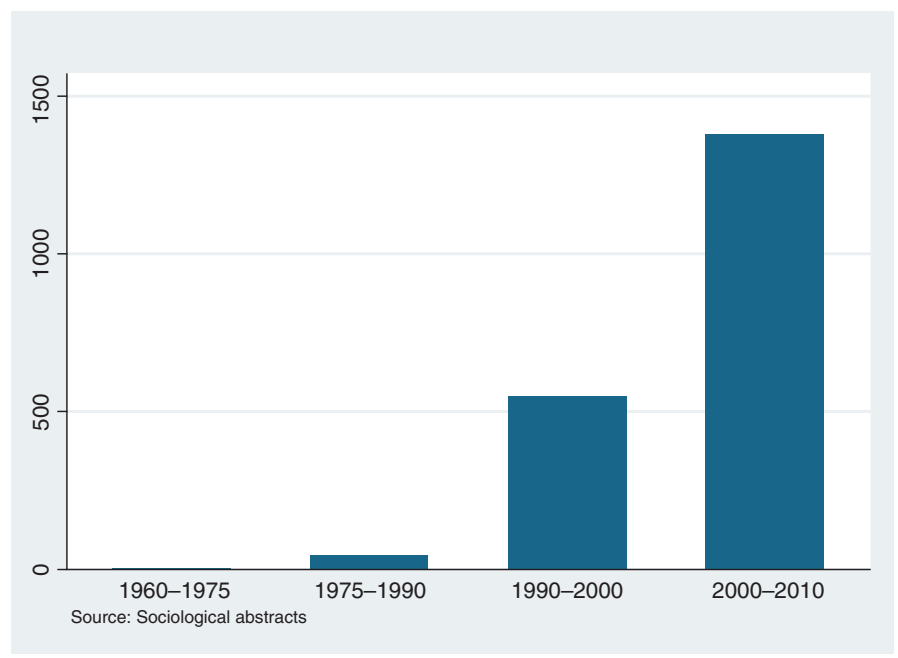

Figure 1 Number of journal abstracts mentioning collective memory, 1960-2010. 
Table 1 Focal concepts in collective memory research.

\begin{tabular}{lll}
\hline Actorhood & Contexts & Formations \\
\hline Memory work & Autobiographical & Recovered \\
Memory project & Historical & Somatic \\
Memory entrepreneurship & Post & Visual \\
& Prosthetic & Cultural trauma \\
& Cosmopolitan & \\
\hline
\end{tabular}

Coming mainly from the symbolic interactionist tradition, the concept of memory entrepreneurs refer to human actors with resources and organisation who do things to remember the past (Fine 2001). The mnemonic artefacts or practices that result from this human activity - marches, processions, museums, Web sites, poetry, song, etc. - constitute memory projects. By their attention to memory entrepreneurs sociologists give attention to the role of agency and actorhood in remembering the past and acknowledge that commemoration does not just happen by chance but requires the active work of people to propagate and disseminate the past (Fine 2001).

With respect to the variable contexts in which memory is constructed, the useful distinction between autobiographical and historical memory owes to the influence of Maurice Halbwachs (Halbwachs 1992). Autobiographical memory has to do with memories of the past based on direct first-hand experience, while historical memory relates to memories of the past mediated through the preservation efforts of others. With the passage of time, one tends to displace the other and open up opportunities for what is termed 'prosthetic memory'. Prosthetic memory closely resembles the historical memory concept by its attention to how people come into contact with memories of the past not through first-hand experience but via mediated cultural representations such as film and cinema (Landsberg 2004). This allows new younger 'post-memory' generations (Hirsch 2008) removed from past events to nonetheless remember them. These two concepts seem to challenge Halbwachs earlier emphasis on the importance of social hosts in the present for keeping memories of the past alive.

All of these theoretical concepts are important, but their utility must ultimately be judged by their confrontation with empirical data. Some of the research discussed in the next section does just that.

\section{Methodological strategies}

Three broad categories of methodological approaches can be identified in the literature (see Table 2) - the statistical use of large-scale social surveys, ethnographic investigation involving the use of in-depth interviews, documentary and textual analysis, and participant observation (either singly or in combination), and studies using comparative historical research. Of course, some studies blend these different approaches, but most, more usually, employ one independently. Cultural analysis of symbolic representations of the past tends to be the main access point for empirically getting at memory (Schuman and Corning 2000). Part of this owes something to researcher investment - it is less costly and time-consuming to look at changes over time in publicly accessible images of some event or figure than it is to ask people about their views and opinions of them via nationally representative surveys. 
Table 2 Collective memory research: methodological approach, level of analysis, focus, examples, and frequency.

\begin{tabular}{|c|c|c|c|c|}
\hline Approach & Level & Focus & Examples & Frequency \\
\hline Social Survey & Micro & $\begin{array}{l}\text { Patterns and } \\
\text { regularities in people's } \\
\text { beliefs about remembered } \\
\text { events/figures }\end{array}$ & $\begin{array}{l}\text { Schuman and Scott 1989; } \\
\text { Schwartz and Schuman 2005; } \\
\text { Schuman et al. } 2005 .\end{array}$ & Moderate \\
\hline Ethnography & Micro & Memory 'on the ground' & $\begin{array}{l}\text { Wagner-Pacifici and Schwartz 1991; } \\
\text { Teeger and Vinitzky-Seroussi 2007; } \\
\text { Conway 2010; Saito 2006;. }\end{array}$ & High \\
\hline $\begin{array}{l}\text { Comparative } \\
\text { Historical }\end{array}$ & Macro & $\begin{array}{l}\text { Memory across } \\
\text { time and space }\end{array}$ & $\begin{array}{l}\text { Spillman 1997; Brubaker and } \\
\text { Feischmidt 2002; Jansen 2007; } \\
\text { Armstrong and Crage 2006; } \\
\text { Levy and Sznaider 2006;. }\end{array}$ & Low \\
\hline
\end{tabular}

It owes more though to theoretical commitments and particularly the tendency to conceive of memory more in static than dynamic, processual terms (Jansen 2007). Because of this, long-range historical accounts are less common in the literature despite calls in recent years from some sociologists of memory (Olick 2008) for the field to go beyond static conceptions of memory to get at the slow-moving temporal processes in its (re)construction. Compared to the analysis of text, it is more difficult to find empirical studies of embodied remembrance (Connerton 1989) - how people remember the past via their physical bodies and in practices such as marches, parades, and processions. Less common still are examples of studies interrogating the complex relationships between textual and embodied memory (Casey 2000; Spillman and Conway 2007).

In what follows I give a brief capsule summary account of three representative examples of each methodological strategy and point the reader towards other interesting illustrations of the method's use. These different methods span levels of analysis from the individual to society.

\section{Statistical use of large-scale social surveys}

One of the best examples of the use of social surveys in collective memory research is Schuman and Scott's study of generational differences in collective memories of past historical events (Schuman and Scott 1989). They make the interesting point - drawing on Karl Mannheim - that when it comes to what memories leave the deepest impression on us, it is not so much how old one is that matters but rather when one was an adolescent and young adult. Based on US data and employing Karl Mannheim's concept of generation, Schuman and Scott investigate whether different generations remember the past differently. Respondents were asked to look back over the previous fifty years and to simply name big national and world events and developments they remembered and why. They found evidence for a generational effect, and they isolate adolescence and early adulthood as the most significant period of one's life in terms of shaping memory.

A second interesting study involving the use of large-scale social survey data, but in this instance relating to a historical figure rather than an historical event or changes is Larson and Lizardo's analysis of Che Guevara as an international mnemonic and political symbol (Larson and Lizardo 2007). Based on data from Spanish respondents, they also take Mannheim's work as their starting point but go beyond it by suggesting that the exposure 
of generations to a wide range of cultural representations of historical figures exerts an important influence on memory. Disaggregating the generation category, they also find some political identity effect - people of a left-wing orientation are more likely, unsurprisingly, to remember Che Guevara than others.

Public beliefs about Christopher Columbus around the time of the $500^{\text {th }}$ anniversary of his coming to America are the focus of Schuman et al. (2005) study. More specifically, they are interested in whether elite opinion about this historical figure maps onto public beliefs about him, and they found that elite efforts to reconstruct his image showed little sign of taking hold among ordinary people. To get at these public beliefs, they carried out a national survey asking over 1500 mostly White American respondents what they would say Columbus did if asked by a niece or nephew to briefly explain his accomplishments. Respondent answers were distributed on a continuum from negative to positive beliefs, and they present statistical tables of these distributions.

Beyond these examples, works by Schuman and Corning (2000) and Schwartz and Schuman (2005) represent good illustrations of the use of the large-scale social survey in memory research.

\section{Ethnographic investigation: in-depth interviews, documentary and textual research, and participant observation}

In the memory literature, numerous examples exist of ethnographic studies employing the standard tools of this method - interviews, observation, and textual analysis. Indeed, one of the paradigmatic pieces of memory research involves the use of ethnographic analysis Wagner-Pacifici and Schwartz's study of the Vietnam memorial (Wagner-Pacifici and Schwartz 1991). This study concerned itself with the basic question of whether commemoration without consensus about the past is possible or not and employed controversies associated with the Vietnam memorial as a case study. Empirically, this study was based on a resort to textual material from newspapers and congressional records and documents about the competition, design, and construction for the memorial, written accounts deposited by people who visited the memorial, observations of the memorial, and objects people deposited at the memorial. They also employed a comparative logic by examining similarities and differences between this memory project and other controversial projects.

Saito's study of Hiroshima in Japanese collective memory provides another example of research employing the ethnographic method. Here, the main source of data is archival and textual materials - he examines memoirs of survivors of the bomb, city government documents contained in archives, and national broadsheet newspapers. Allied to this, he carefully studied existing secondary sources about the historical evolution of Japanese society. Based on this, Saito proposes a three-phase periodisation of Japanese engagement with the memory of the event with an early period focusing on transnational commemoration to later national engagement with it, and still later to the congealing of both national and transnational elements (Saito 2006).

If most collective memory research pays attention to examples of successful commemoration, Jennifer Jordan's recent work on memorialisation in the material landscape of urban Berlin represents a corrective to this approach of looking under the lamp-post to find memory. Jordan draws on archival material, interviews, and secondary sources to show that studying and understanding negative cases of unsuccessful remembrance discussed in the literature under the rubrics of forgetting, silencing, amnesia, and oblivion (Connerton 2008; Huyssen 2005; Ricouer 2004; Schwartz 2009; Sturken 1998; Trouillot 1995; Walkowitz and Knauer 2004) - has much to teach us about the dynamics of 
memory than the more frequent default option of studying successful commemoration. Her focus on where the plaque, statue, memorial, or museum is not tells us that successful commemoration critically depends on cultural factors such as the presence or absence of memory entrepreneurs and the resonance of their activities, as well as bureaucratic issues such as land usage and land ownership (Jordan 2006).

Other interesting empirical studies of memory research using ethnographic approaches include Vinitzky-Seroussi (2002), Teeger and Vinitzky-Seroussi (2007), Yoneyama (1999), Conway (2010), and Spillman and Conway (2007).

\section{Comparative historical research}

Studies of how a single event is remembered in different societies at different times or of how different events are remembered in similar societies are rare in this sub-field. Some interesting examples of research using a comparative historical logic are Spillman (1997), Levy and Sznaider (2006), Brubaker and Feischmidt (2002), and Armstrong and Crage (2006).

Spillman's study of centennial and bicentennial anniversaries in the two settler societies of United States and Australia examines variation in commemorative themes adopted at different times in these two societies. This study found that American political elites remembered their founding moment as a nation much more than Australian elites did and she explained this interesting variation in terms of the cultural production of the past - arguing for the importance of paying attention to the audiences to whom elites were oriented to as well as variation between the two societies in terms of the salience of international image and reputation - but also in terms of variation in the semiotic qualities of historical symbolism.

The study of the similarities and differences in the commemoration of the 1848 revolution in Hungary, Slovakia, and Romania is the focus of Brubaker and Feischmidt's comparative work. They examined what memory choreographers said at commemorative occasions - political discourse - and newspaper and popular press coverage but, significantly, and with the help of student assistants, they also participated as observers in recent commemorations and paid special attention to the emotional atmosphere generated by them. Examining the different meanings of 1848 across space and time, they found that 1848 was more resonant in Hungary than in either Slovakia or Romania and that it evoked a different emotional atmosphere and fuelled different political claim-making at different times. They explain this variation as a consequence of how salient or not the 1848 revolution was to national group identity - in Hungary it was much more salient. Tracing the trajectory of Hungarian commemorations, they found that commemorations of 1848 did different things in different contexts - they moved from being sombre to more celebratory occasions as a result of growing concerns about Hungary's international image and standing and demonstrating its credentials as a modern polity worthy of admission to transnational institutions such as the European Union.

Another recent contribution to comparative historical studies of memory projects is Armstrong and Crage's (2006) work on the Stonewall riots in New York City and similar events in other metropolitan cities and how they were differently remembered in different gay communities. Drawing on archival data about gay movements and secondary literature, they investigate variation between three US cities in terms of how incidents involving gay opposition to police raids of gay bars got commemorated. Explaining this variation, they isolate the importance of factors such as 'mnemonic capacity' or the ability of social groups to pull of a commemoration, the resonance of memory projects and 
relationship to wider political movements, the chosen commemorative device, and the 'commemorability' of events.

Other notable recent studies using comparative historical research include Jansen (2007) and Levy and Sznaider (2006).

\section{Methodological challenges}

Although it is unusual for sociologists of memory to offer reflective comments on the actual process of carrying out research on commemoration, a few examples do exist and almost exclusively within the ethnographic tradition. Viterna's reflections on fieldwork in rural El Salvador (Viterna 2009) points out that students of memory run up against two common validity problems when it comes to asking people questions about their memories of the past. One common difficulty is that people tend to be prone to sheer forgetfulness or, put another way, recall problems (Jedlowski 2001) - as time passes our memories of what happened tend to fade as new experiences compete with old ones for retention in our minds. Vromen's study of Roman Catholic Church rescue efforts on behalf of Jewish children during the Holocaust provides an instructive example of this when asked about daily life in Belgian convents nuns tended to forget, for example, precise details of practices in relation to the daily washing of the children in their care. Vromen employed letters the nuns wrote to flesh out some of the detail about their lives missing from their interview accounts and this provides an example of how textual data can supplement interview data in our memory research (Vromen 2008, 65).

Another difficulty in relation to interviewing people about the past is the tendency of interviewees to sanitise their retellings in the context of the contemporary 'remembrance environment' (Viterna 2009, 283) - for example, Vromen's study reports that courageous nuns who ran these institutions tended to de-emphasise the importance of saving souls - via participation in Catholic rituals such as baptism - as their goal and emphasised instead humanitarian concerns in interviews she carried out with some nuns long after what happened (Vromen 2008, 51-52). Respondent recollections can also be hampered by audience effects and subsequent post-event stories told by others (Hirst and Echterhoff 2008).

Of course, researchers can take steps to correct for these deficiencies in their empirical data gathering - the accounts of respondents can be corroborated or cross-checked against available textual evidence from newspaper accounts and archival records, for instance.

To my knowledge, no reflective pieces by sociologists using social surveys or comparative historical research exist. The challenges of empirically investigating memory using these kinds of strategies are the challenges of social survey research - dealing with the lack of equivalence of survey question meanings across surveys, for example - and comparative historical research - selecting pertinent cases and sacrificing breadth of coverage for depth of understanding, for instance - more generally.

\section{Future directions}

Collective memory is central to how individuals and collectivities conceive of their identities. Sociological engagements with it spotlight how we mobilise resources from the social world to bring the past into the present and the implications of this for identity, power, and social change (Jedlowski 2001; Olick and Robbins 1998). Back in the late 1990s, Olick and Robbins (1998) lamented the lack of unity in the discipline's efforts to do this. The earlier mentioned developments herald some trend towards greater unity 
though only in a weak sense can the field be said to be unified because innovations either at a methodological or at a theoretical level - tend to be ad hoc and slow to diffuse widely across disciplinary boundaries. Oddly, students of memory tend to be prone to "selective forgetting" in relation to developments in cognate fields.

Future development of the field will likely turn on progress made - or not - on two fronts: (1) internal cohesion and (2) external utility.

Internally, the sociology of commemoration would benefit from putting the interconnection between theory and data front-and-centre - how sociologists theorise about the nature of memory has important consequences for how they empirically study it (and vice versa). Consider two examples. First, sociologists have been interested in the social forces that shape the production of memory via attention to memory entrepreneurship, for example, but this angle of vision has meant that their understanding of how mnemonic artefacts and practices are received or consumed by ordinary people - the reception issue - is somewhat underdeveloped. Indeed, it is rare to find a study that actually asks people what they think and feel about commemorative projects. We tend instead to read off this layer of interpretation and meaning-making from the intentions of those behind memory projects or from shifting symbolic representations. But given the highly charged nature of memory debates we know that these intentions do not always neatly articulate with those of individuals at the other end - in this respect, sociological engagement with the experimental studies of psychologists on memory and their efforts to 'bring the individual back in' through them might well be fruitful (Hirst and Echterhoff 2008; Schwartz and Schuman 2005).

Second, conceiving of collective memory in "moving picture" (Pierson 2004, 2) terms calls for sensitivity to long-range historical change and understanding one case in relation to others. More use of comparative historical logics would allow an examination of cross-national variation in how the same event or figure is remembered in different national contexts at different times or how similar events are remembered in similar societies. As we have seen in the classification of memory research presented earlier, these methodological approaches are less common than other data gathering strategies. Also underrepresented is the use of mixed-method designs combining qualitative and quantitative data gathering though some notable examples of this do exist (Schuman et al. 2005).

On an external level, against a 'picket-fence' approach emphasising the separation of memory research from other sub-fields in sociology the field could fruitfully benefit from paying more attention to how it can contribute to other sub-fields - for example, the sociology of organisations might benefit from attention to how organisations of many kinds have their own "memories," and how this organisational memory potentially shapes - or not - present-day organisational behaviour. Beyond this example, almost every social phenomenon from collective action (Armstrong and Crage 2006) to eating behaviour (Lee 2000; Sutton 2008) can be said to have a "memory" dimension. Although up to now the sociology of memory has not contributed much by way of concepts and theories to the broader discipline, the study of collective memory opens up rich possibilities for exercising the 'sociological imagination' (Mills 2000).

\section{Acknowledgement}

The author thanks the anonymous reviewers and the section editor, Arlene Stein, for very helpful and thoughtful comments on an earlier version of this article. 


\section{Short Biography}

Brian Conway is lecturer in the Department of Sociology at the National University of Ireland, Maynooth. His research interests are collective memory, sociology of religion, and the history of sociology. Previously, he lectured in sociology in the School of Applied Social Studies at the Robert Gordon University, Scotland. He was awarded a B.Soc.Sc. degree by University College Dublin, a M.S.W. degree by the University of Pittsburgh, and M.A. and Ph.D. degrees in sociology by the University of Notre Dame. His work has been published in Sociological Inquiry, Journal of Urban Affairs, Memory Studies, Identity, Cultural Sociology, Symbolic Interaction, Sociological Origins, and Nomadic Peoples, and a number of edited collections. He is author of Commemoration and Bloody Sunday: Pathways of Memory (Palgrave Macmillan, 2010) and associate editor of Sociological Origins.

\section{Note}

* Correspondence address: Brian Conway, Department of Sociology, National University of Ireland, Maynooth, Maynooth, Co. Kildare, Republic of Ireland. E-mail: brian.conway@nuim.ie

\section{References}

Alexander, J. C. 2003. 'Cultural Trauma and Collective Identity.' Pp. 85-107 in The Meanings of Social Life: A Cultural Sociology, edited by J. C. Alexander. Oxford: Oxford University Press.

Armstrong, E. A. and S. M. Crage 2006. 'Movements and Memory: The Making of the Stonewall Myth.' American Sociological Review 71(5): 724-51.

Brubaker, R. and M. Feischmidt 2002. '1848 in 1998: The Politics of Commemoration in Hungary, Romania, and Slovakia.' Comparative Study in Society and History 44(4): 700-44.

Casey, E. S. 2000. Remembering: A Phenomenological Study, 2nd edn. Bloomington: Indiana University Press.

Connerton, P. 1989. How Societies Remember. Cambridge: Cambridge University Press.

Connerton, P. 2008. 'Seven Types of Forgetting.' Memory Studies 1(1): 59-71.

Conway, B. 2010. Commemoration and Bloody Sunday: Pathways of Memory. Basingstoke/New York: Palgrave Macmillan.

Corney, F. C. 2003. 'Rethinking a Great Event: The October Revolution as Memory Project.' Pp. 17-42 in States of Memory: Continuities, Conflicts, and Transformations in National Retrospection, edited by J. K. Olick. Durham: Duke University Press.

Durkheim, É. 1995 (translated by K. E. Fields). The Elementary Forms of Religious Life. New York: The Free Press.

Fine, G. A. 2001. Difficult Reputations: Collective Memories of the Evil, Inept, and Controversial. Chicago: University of Chicago Press.

Gibbons, L. 2001. 'Where Wolfe Tone's statue was not': Joyce, monuments and memory.' Pp. 139-59 in History and Memory in Modern Ireland, edited by I. McBride. Cambridge: Cambridge University Press.

Gillis, J. (ed.) 1994. Commemorations: The Politics of National Identity. Princeton: Princeton University Press.

Halbwachs, M. 1992. (translated and edited by L. A. Coser). On Collective Memory. Chicago: University of Chicago Press.

Hervieu-Léger, D. 2000. Religion as a Chain of Memory. New Brunswick, NJ: Rutgers University Press.

Hirsch, M. 2008. 'The Generation of Postmemory.' Poetics Today 29(1): 103-28.

Hirst, W. and G. Echterhoff 2008. 'Creating Shared Memories in Conversation: Toward a Psychology of Collective Memory.' Social Research 75(1): 183-216.

Huyssen, A. 2005. 'Resistance to Memory: The Uses and Abuses of Public Forgetting.' Pp. 165-84 in Globalizing Critical Theory, edited by M. Pensky. New York: Rowman and Littlefield.

Irwin-Zarecka, I. 1994. Frames of Remembrance: The Dynamics of Collective Memory. New Brunswick: Transaction Publishers.

Jansen, R. S. 2007. 'Resurrection and Appropriation: Reputational Trajectories, Memory Work, and the Political Use of Historical Figures.' American Journal of Sociology 112(4): 953-1007.

Jedlowski, P. 2001. 'Memory and Sociology: Themes and Issues.' Time E Society 10(1): 29-44.

Jordan, J. 2006. Structures of Memory: Understanding Urban Change in Berlin and Beyond. Stanford: Stanford University Press.

Landsberg, A. 2004. Prosthetic Memory: The Transformation of American Remembrance in the Age of Mass Culture. Columbia: Columbia University Press. 
Larson, J. and O. Lizardo 2007. 'Generations, identities and the collective memory of Che Guevara.' Sociological Forum 22: 425-51.

Lee, S. 2000. 'Dys-appearing Tongues and Bodily Memories: The Aging of First-Generation Resident Koreans in Japan.' Ethos 28: 198-223.

Levy, D. and N. Sznaider 2006. The Holocaust and Memory in the Global Age. Philadelphia: Temple University Press. Lewis, J. D. and A. J. Weigert 1981. 'The Structures and Meanings of Social Time.' Social Forces 60(2): $432-62$.

Mills, C. W. 2000. The Sociological Imagination. Oxford: Oxford University Press.

Misztal, B. 2003. 'Durkheim on Collective Memory.' Journal of Classical Sociology 3(2): 123-43.

Nora, P. 1989. 'Between Memory and History: Les lieux de mémoire.' Representations 26: 7-24.

Olick, J. 2008. 'From Collective Memory to the Sociology of Mnemonic Practices and Products.' Pp. 151-61 in Cultural Memory Studies: An International and Interdisciplinary Handbook, edited by A. Erll and A. Nünning. Berlin: Walter de Gruyter.

Olick, J. K. and J. Robbins 1998. 'Social Memory Studies: From "Collective Memory" to the Historical Sociology of Mnemonic Practices.' Annual Review of Sociology 24: 105-40.

Pierson, P. 2004. Politics In Time: History, Institutions, and Social Analysis. Princeton: Princeton University Press.

Ricouer, P. 2004. Memory, History, Forgetting. Chicago: University of Chicago Press.

Saito, H. 2006. 'Reiterated Commemoration: Hiroshima as National Trauma.' Sociological Theory 24: 353-76.

Schuman, H. and A. D. Corning 2000. 'Collective Knowledge of Public Events: The Soviet Era from the Great Purge to Glasnost.' American Journal of Sociology 105(4): 913-56.

Schuman, H. and J. Scott 1989. 'Generations and Collective Memory.' American Sociological Review 54: 359-81.

Schuman, H., B. Schwartz and H. D’Arcy 2005. 'Elite Revisionists and Popular Beliefs: Christopher Columbus, Hero or Villain?'. Public Opinion Quarterly 69(1): 2-29.

Schwartz, B. 2009. 'Collective Forgetting And The Symbolic Power Of Oneness: The Strange Apotheosis of Rosa Parks.' Social Psychology Quarterly 72(2): 123-42.

Schwartz, B. and M. Kim (eds.) forthcoming. Northeast Asia's Difficult Past: Studies in Collective Memory. Basingstoke/New York: Palgrave Macmillan.

Schwartz, B. and H. Schuman 2005. 'History, Commemoration, and Belief: Abraham Lincoln in American Memory, 1945-2001.' American Sociological Review 70(2): 183-203.

Spillman, L. 1997. Nation and Commemoration: Creating National Identities in the United States and Australia. Cambridge: Cambridge University Press.

Spillman, L. and B. Conway 2007. 'Texts, Bodies, and the Memory of Bloody Sunday.' Symbolic Interaction 30(1): 79-103.

Sturken, M. 1998. 'The Remembering of Forgetting: Recovered Memory and the Question of Experience.' Social Text 57 16(4): 103-125.

Sutton, D. 2008. 'A Tale of Easter Ovens: Food and Collective Memory.' Social Research 75(1): 157-80.

Teeger, C. and V. Vinitzky-Seroussi 2007. 'Controlling for Consensus: Commemorating Apartheid in South Africa.' Symbolic Interaction 30(1): 57-78.

Trouillot, M. 1995. Silencing the Past: Power and the Production of History. Boston: Beacon Press.

Tsutsui, K. 2009. 'The Trajectory of Perpetrators' Trauma: Mnemonic Politics around the Asia-Pacific War in Japan.' Social Forces 87(3): 1389-422.

Vinitzky-Seroussi, V. 2002. 'Commemorating A Difficult Past: Yitzhak Rabin's Memorials.' American Sociological Review 67: 30-51.

Viterna, J. 2009. 'Negotiating the Muddiness of Grassroots Field Research: Managing Identity and Data in Rural El Salvador.' Pp. 271-97 in Women Fielding Danger: Negotiating Ethnographic Identities in Field Research, edited by M. K. Huggins and M. -L. Glebbeek. Lanham: Rowman \& Littlefield.

Vromen, S. 2008. Hidden Children of the Holocaust: Belgian Nuns and Their Daring Rescue of Young Jews from the Nazis. Oxford: Oxford University Press.

Wagner-Pacifici, R. and B. Schwartz 1991. 'The Vietnam veterans memorial: Commemorating a difficult past.' American Journal of Sociology 97: 376-420.

Walkowitz, D. J. and L. M. Knauer (eds.) 2004. Memory and the Impact of Political Transformation in Public Space. Durham: Duke University Press.

Yoneyama, L. 1999. Hiroshima Traces: Time, Space and the Dialectics of Memory. Berkeley: University of California Press.

Zelizer, B. 2002. 'Finding Aids to the Past: Bearing Personal Witness to Traumatic Public Events.' Media, Culture E Society 24: 697-714.

Zerubavel, E. 1997. Social Mindscapes: An Invitation to Cognitive Sociology. Cambridge: Harvard University Press. 